\title{
BIOCHEMICAL PHENOMENON OF PALMITIC ACID AND ITS REPRESENTATION IN CELLULAR ORGANISMS
}

\author{
ANDREY SKRYL ${ }^{1}$, SHAPOVALOV SERGEY², and Aleksey Udovenko ${ }^{1}$ \\ ${ }^{1}$ National Technical University Kharkiv Polytechnic Institute \\ ${ }^{2}$ Affiliation not available
}

October 16, 2020

\begin{abstract}
In our opinion, the question of the role of saturated fatty acids in the regulatory processes of living organisms was undeservedly relegated to the background. In this paper, we set a goal to generalize data on the role and distribution in organisms of various classes of one of the dominant in the composition of saturated fatty acids - palmitic acid.
\end{abstract}

\section{Hosted file}

Biochemical phenomenon of PA eng 22.09.2020.pdf available at https://authorea.com/users/ 367842/articles/487104-biochemical-phenomenon-of-palmitic-acid-and-its-representationin-cellular-organisms

\section{Hosted file}

Table 1.pdf available at https://authorea.com/users/367842/articles/487104-biochemicalphenomenon-of-palmitic-acid-and-its-representation-in-cellular-organisms

\section{Hosted file}

Table 2.pdf available at https://authorea.com/users/367842/articles/487104-biochemicalphenomenon-of-palmitic-acid-and-its-representation-in-cellular-organisms

\section{Hosted file}

Table 3.pdf available at https://authorea.com/users/367842/articles/487104-biochemicalphenomenon-of-palmitic-acid-and-its-representation-in-cellular-organisms

\section{Hosted file}

Table 4.pdf available at https://authorea.com/users/367842/articles/487104-biochemicalphenomenon-of-palmitic-acid-and-its-representation-in-cellular-organisms

\section{Hosted file}

Table 5.pdf available at https://authorea.com/users/367842/articles/487104-biochemicalphenomenon-of-palmitic-acid-and-its-representation-in-cellular-organisms

\section{Hosted file}

Table 6.pdf available at https://authorea.com/users/367842/articles/487104-biochemicalphenomenon-of-palmitic-acid-and-its-representation-in-cellular-organisms

\section{Hosted file}


Figure 1.pdf available at https://authorea.com/users/367842/articles/487104-biochemicalphenomenon-of-palmitic-acid-and-its-representation-in-cellular-organisms

\section{Hosted file}

Figure 2.pdf available at https://authorea.com/users/367842/articles/487104-biochemicalphenomenon-of-palmitic-acid-and-its-representation-in-cellular-organisms

\section{Hosted file}

Figure 3.pdf available at https://authorea.com/users/367842/articles/487104-biochemicalphenomenon-of-palmitic-acid-and-its-representation-in-cellular-organisms 